\title{
CORRElating BUlK DENSITY (WITH DOCKAGE) AND TEST WeIGHT (WITHOUT DOCKAGE) FOR WHEAT SAMPLES
}

\author{
R. Bhadra, M. E. Casada, J. M. Boac, A. P. Turner, S. A. Thompson, \\ M. D. Montross, R. G. Maghirang, S. G. McNeill
}

\begin{abstract}
In grain bins, the compaction of stored grain is caused by the overbearing pressure of the bulk material in the bin. To predict the amount of grain in the bin, compaction values must be determined based on the average bulk density (BD) of the stored material. However, BD is determined following the Federal Grain Inspection Service (FGIS) guidelines for measuring test weight (TW), which require that dockage be removed prior to measuring wheat $T W$. Thus, this creates a problem for predicting grain compaction and conducting inventory studies, because the average $B D$ of the grain in a bin for these calculations should include dockage. Therefore, regression models between the $T W$ without dockage and the $B D$ with dockage were obtained based on the reported scale data during wheat harvest from three elevators located in Kansas and Oklahoma. A power model was used to predict BD with dockage when $T W$ without dockage and dockage levels are given. Laboratory samples of HRW and SRW wheat with dockage levels ranging from $0.05 \%$ to $5 \%$ showed a second order polynomial trend when plotted against decrease in BD with dockage values compared to TW without dockage. These results will be crucial for determining grain packing inventory parameters for HRW wheat bins.
\end{abstract}

Keywords. Dockage, HRW, SRW, Stored grain inventory, Test weight, Wheat.

A gricultural grains such as wheat, corn, and soybeans are compressible materials and, in storage, they are affected by pressure from overbearing loads. However, the degree of compressibility of stored grain varies with grain type, grain properties, and the geometry of the bin in which the grain is stored. Several studies have investigated the compressibil-

Submitted for review in December 2015 as manuscript number PRS 11692; approved for publication as a Technical Note by the Processing Systems Community of ASABE in September 2016.

Mention of company or trade names is for description only and does not imply endorsement by the USDA. The USDA is an equal opportunity provider and employer.

The authors are Rumela Bhadra, ASABE Member, Research Associate, Department of Biological and Agricultural Engineering, Kansas State University, Manhattan, Kansas; Mark E. Casada, ASABE Member, Research Agricultural Engineer, USDA-ARS Center Grain and Animal Health Research (CGAHR), Stored Product Insect and Engineering Research Unit (SPIERU), Manhattan, Kansas; Josephine M. Boac, ASABE Member, formerly Research Associate, Department of Biological and Agricultural Engineering, Kansas State University, Manhattan, Kansas; Aaron P. Turner, Agricultural Engineer, Department of Biosystems and Agricultural Engineering, University of Kentucky, Lexington, Kentucky; Sidney A. Thompson, ASABE Member, Professor, College of Engineering, University of Georgia, Athens, Georgia; Michael D. Montross, ASABE Member, Professor, Department of Biosystems and Agricultural Engineering, University of Kentucky, Lexington, Kentucky; Ronaldo G. Maghirang, ASABE Member, Professor, Department of Biological and Agricultural Engineering, Kansas State University, Manhattan, Kansas; and Samuel G. McNeill, ASABE Member, Associate Extension Professor, Department of Biosystems and Agricultural Engineering, University of Kentucky, Princeton, Kentucky. Corresponding Author: Mark E. Casada, USDA-ARS CGAHR SPIERU, 1515 College Ave., Manhattan, KS; phone: 785-776-2758; email:mark.casada@ars.usda.gov. ity of a variety of food crops, such as ground shelled corn, wheat, corn, soybean, corn meal, sugar beet pulp, cotton seed meal, and distillers grains without solubles (Loewer et al., 1977; Malm and Backer, 1985; Bhadra et al., 2015; Boac et al., 2015). Milani et al. (2000) determined that the effects of pressure and moisture on bulk densities of soybean were independent of variety). Additional studies have been conducted related to the effect of grain spreaders on the bulk density (BD) of stored wheat, yellow corn, and sorghum (Chang et al., 1981) and different methods of transfer, such as choke fed and non-choke fed through an orifice (Chang et al., 1983).

Janssen's (1895) equation is commonly used to predict the vertical and lateral pressures in bins and is based on the $\mathrm{BD}$ of the stored material, coefficient of friction, lateral to vertical pressure coefficient and the bin geometry. Studies have also been conducted in which the degree of compressibility or packing of grain in bins has been estimated using the differential form of Janssen's equation (Thompson and Ross, 1983; Thompson et al., 1987; McNeill et al., 2008). Grain packing models based on this form of Janssen's equation were adopted as an ASAE standard in 1992 and later revised in 2010 (ASABE Standards as EP413.2, 2010, R2014).

Inventory control of stored grain is extremely important for farmers, elevator managers, and bin designers and is crucial for the grain bin managers, who must track the quantity of the crop and meet federal and state regulatory obligations. Each truck load of grain stored in a bin is sampled and quality parameters measured following standards in the USDA Federal Grain Inspection Service 
(FGIS) Handbook (USDA-GIPSA, 2009). Official inspection of grain by a state or federal regulatory body can only be conducted using FGIS-approved equipment and procedures. For wheat, the moisture content, dockage, TW, and percent of shrunken and broken kernels are the most important extrinsic parameters measured as per FGIS guidelines.

When grain is delivered to elevators, samples of wheat, including Hard Red Winter (HRW) and Soft Red Winter (SRW) classes, are taken from incoming trucks or trailers using mechanical probes. These samples are evaluated for moisture content before the removal of dockage, and evaluated for TW after the dockage has been removed (USDA-GIPSA, 2009). Dockage is the material other than the predominant grain that can easily be removed with sieves and cleaning devices, the detailed definition is given in the Materials and Methods section.

Test weight is defined as the weight of the volume of grain that is required to fill a Winchester bushel $\left(2,150.42\right.$ in. $\left.^{3}\right)$ to capacity (USDA-GIPSA, 2009). The unit of TW is then $\mathrm{lb} / \mathrm{bu}$. Thus, the TW measures the BD under specific conditions (Bern and Brumm, 2009) including, in the case of wheat, that the dockage has been removed. This standard procedure of removing the dockage before TW evaluation creates a problem for grain packing models. The models need $\mathrm{BD}$ with dockage as an input to calculate grain packing. The $\mathrm{BD}$ without dockage, measured following FGIS guidelines, will be denoted as test weight (TW) throughout this article, following the grain industry norm, and distinguished from bulk density with dockage, measured with the same device. There is no data in the literature on the relationship between TW (without dockage) and $\mathrm{BD}$ with dockage for wheat. Furthermore, field-observed dockage levels are commonly less than $1 \%$, but can range higher under rare scenarios. Hence, it would be useful to determine the effects of dockage levels of up to $5 \%$ to include the extreme levels and to evaluate correlation trends, which should be clearer with the inclusion of higher dockage levels. Thus, the objectives of this research were to: (1) develop a regression model for predicting the BD with dockage from the FGIS-measured TW and the FGISmeasured dockage values in the field and (2) evaluate the effect of dockage on the BD of wheat samples for dockage levels up to $5 \%$. Samples at above $1 \%$ dockage cannot be readily obtained from the field and will need to be prepared in the laboratory.

\section{MATERIALS AND METHODS \\ Test Weight Data Collection}

The FGIS-approved TW apparatus consists of a hopper discharge container with a slide gate and a one dry quart cup (Seedburo Equipment, Chicago, Ill.). The weight of grain in the quart cup is measured in pounds and is multiplied by 32 (number of dry quarts in a Winchester bushel) to obtain the TW in pounds per bushel $(\mathrm{lb} / \mathrm{bu})$ as described in the handbook (USDA-GIPSA, 2009). According to FGIS standards, the minimum TW per bushel for HRW wheat should range from 51.0 to $60.0 \mathrm{lb} / \mathrm{bu}$ for all
U.S. wheat grades No. 1 to No. 5 (Matz, 1991) with the standard bushel weight of one bushel of wheat equal to $60 \mathrm{lb}$.

TW data for HRW wheat were collected from three different elevators located in northeast Kansas (Manhattan, Kan.), northern Oklahoma (Enid, Okla.), and western Kansas (Goodland, Kan.) during wheat harvest season in 2011 and 2013. Trucks were sampled as they arrived at the scale and sample test weights without dockage, following FGIS procedures, were obtained directly from scale data reports from the elevator managers. FGIS standards (USDA-GIPSA, 2009) define dockage primarily as the foreign material that is lighter, larger, or smaller than grain. Also, it is the underdeveloped shriveled and small pieces of wheat kernels that is removed from separated wheat, but cannot be recovered by properly rescreening or recleaning. The unthreshed kernels that pass over the riddle (in the Carter dockage tester) are also considered dockage.

A moisture content analysis was also performed for those samples. The moisture content of the field samples ranged from $10.0 \%$ to $12.9 \%$ (wb), with an average of $11.5 \%$ (wb). Before discarding the samples from each truck, dockage and cleaned grain from the sample were mixed together uniformly and the resulting BD (with dockage) was measured. Thus, TW (without dockage), BD (with dockage), and moisture content were measured from the same sample from each truck load.

Separate clean wheat samples were procured from four states in the United States (Kansas, Kentucky, Oklahoma, and Texas) and mixed with dockage from a commercial flour mill at varying levels ranging from $0.05 \%$ to $5 \%$ by weight for laboratory tests to determine the $\mathrm{BD}$. This part of the dataset was used in the second part of the analysis where we determined the change in $\mathrm{BD}$ with dockage levels. Since field samples only rarely have more than $1 \%$ dockage it was necessary to prepare laboratory samples with these higher dockage levels. The wheat samples from Kansas, Oklahoma, and Texas were HRW wheat, while the wheat sample from Kentucky was SRW wheat. The moisture contents for the laboratory wheat samples ranged from $8.8 \%$ to $13.3 \%$ (wb). Lab samples with the discrete dockage levels were compared to the field samples after grouping the field samples by dockage level in $0.1 \%$ increments. Based on the observed standard deviations, and the $\mathrm{z}$-value for a $5 \%$ margin of error, the minimum number of observations should be 20 , so the field samples were grouped in $0.1 \%$ increments for cases where at least 20 observations were in the dataset. The lab samples (sample size of $3 \mathrm{~kg}$ ) were also split into three $1 \mathrm{~kg}$ subsamples. Each subsample had TW measurements repeated for 10 times, yielding 30 total measurements, for each dockage level.

\section{Data Analysis}

The measured decrease in $\mathrm{BD}$ with dockage when compared to TW values was plotted and analyzed for each dockage level. A statistical analysis was performed using both single and multiple regression techniques for correlating BD (with dockage) with TW (without dockage). 
The single regression analysis was performed using Microsoft Excel 2007 (Redmond, Wash.), and samples were classified based on 4 different dockage levels: $0 \%$ to $0.39 \%, 0.4 \%$ to $0.59 \%, 0.6 \%$ to $0.9 \%$, and $1 \%$ and above. The multiple regression analysis was performed using CurveExpert Professional software (version 2.0.3, 2013) to predict $\mathrm{BD}$ with dockage as a function of dockage level and TW without dockage.

Multiple regression models for predicting $\mathrm{BD}$ with dockage as a function of TW and dockage level were evaluated using CurveExpert Professional software. Since a true $\mathrm{R}^{2}$ does not exist for the nonlinear models, standard error and the Akaike Information Criterion (AIC) were used to select the best model. AIC is a statistical parameter that strikes a balance between the goodness of fit of a model and the complexity of the model (Akaike, 1974):

$$
\mathrm{AIC}=2 \mathrm{k}-2 \ln (\mathrm{L})
$$

where

$\mathrm{k}=$ number of parameters in the statistical model.

$\mathrm{L}=$ maximized value of the likelihood function of the estimated model.

The preferred model will have the lowest AIC value. This technique includes a penalty prediction that discourages any increase in the number of parameters that can lead to overfitting and a higher goodness of fit (Fang, 2011).

\section{RESUlTS AND DisCUSSION}

All field data (Enid, Okla.; Manhattan, Kan.; and Goodland, Kan.) are shown in figure 1 with $\mathrm{BD}$ with dockage as a linear function of TW (without dockage). The simple linear model (no intercept) had a slope of 0.986 and an $\mathrm{R}^{2}$ of 0.724 . In this raw plot the effect of varying levels of dockage only appears as scatter. The Goodland data show by far the greatest scatter of the three locations in figure 1, apparently caused by high dockage levels observed during an unusually rainy harvest season in 2011 (dockage in the Goodland samples ranged up to $3 \%$ compared to a maximum of $1 \%$ for the other two locations). A simple linear model without the Goodland data had a slope of 0.992 and an $\mathrm{R}^{2}$ of 0.886 . Neither of these correlations include the level of dockage as an independent variable.

\section{Multiple Regression}

Table 1 shows the best three models from the multiple regression analysis along with two simple linear correlations between BD and TW. Numerous other nonlinear models were evaluated with CurveExpert Pro but they did not produce as good fit as these three. Power Model 1 yielded the least AIC value of -258 and near the best standard error value at 0.880 . For these models similar standard errors indicate that the differences between predictions were small. Both the Two-Variable Linear Model and Power Model C (table 1) suffer from a discontinuity at dockage $=0 \%$. However, in this case TW

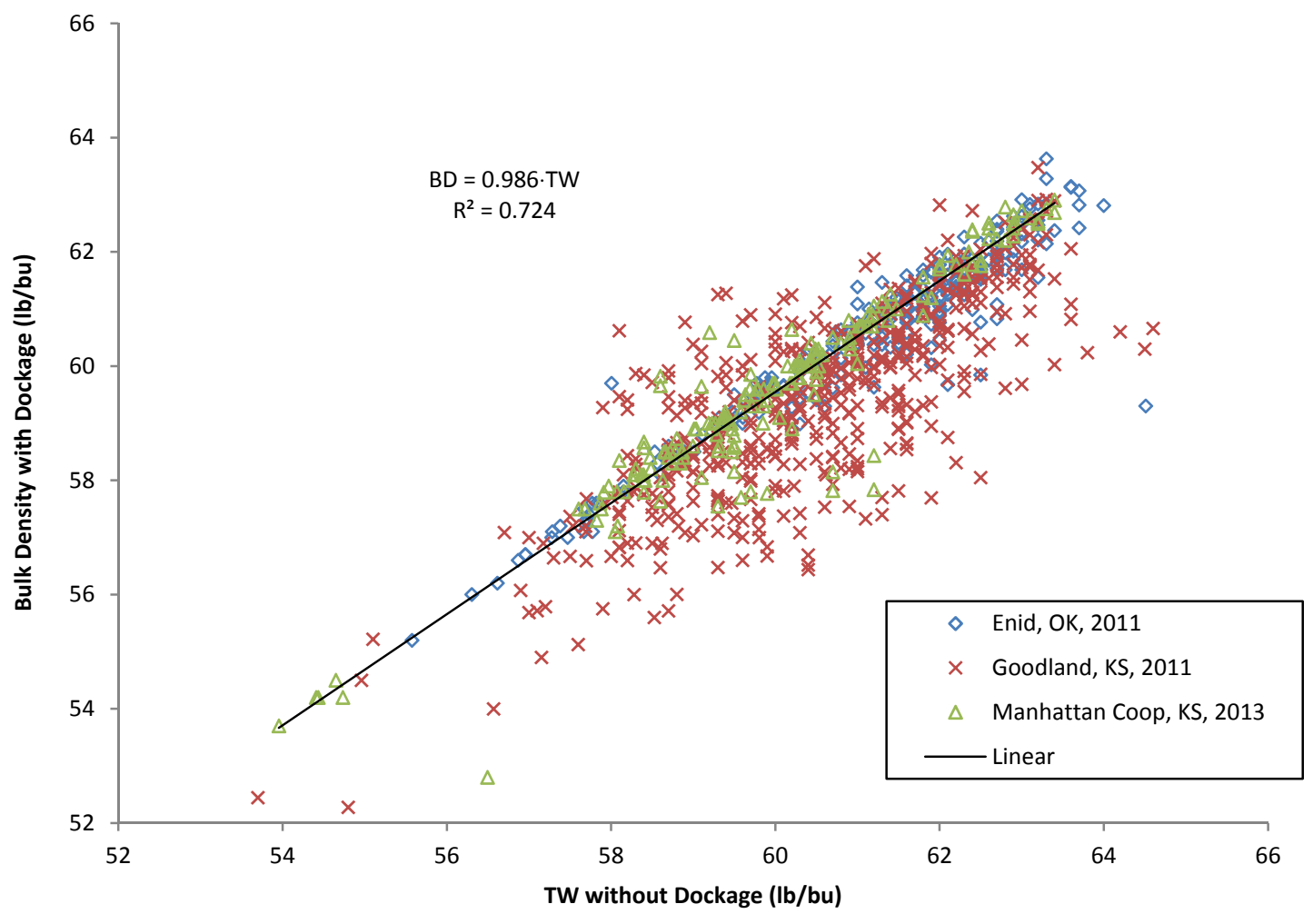

Figure 1. Bulk density vs. test weight of HRW wheat samples with dockage from $0 \%$ to $3.6 \%$. 
Table 1. Selected models for predicting bulk density with dockage from test weight and dockage level. ${ }^{[a]}$

\begin{tabular}{|c|c|c|c|c|c|c|c|}
\hline \multirow{2}{*}{$\begin{array}{c}\text { Model } \\
\text { Name }\end{array}$} & \multirow[b]{2}{*}{ Model Structure } & \multirow[b]{2}{*}{$\mathrm{AIC}$} & \multirow{2}{*}{$\begin{array}{c}\text { Std Error } \\
(\mathrm{lb} / \mathrm{bu})\end{array}$} & \multicolumn{4}{|c|}{ Parameter Estimates } \\
\hline & & & & $\mathrm{a}$ & $\mathrm{b}$ & $\mathrm{c}$ & $\mathrm{d}$ \\
\hline \multicolumn{8}{|c|}{ Single-Variable Models, $B D=f(T W)$} \\
\hline Simple Linear & $\mathrm{BD}=\mathrm{a}(\mathrm{TW})$ & -172.3 & 0.915 & 0.986 & & & \\
\hline 1-Variable Linear & $\mathrm{BD}=\mathrm{a}+\mathrm{b}(\mathrm{TW})$ & -211.9 & 0.896 & 6.66 & 0.876 & & \\
\hline \multicolumn{8}{|c|}{ Two-Variable Models, $B D=f(T W, d k)$} \\
\hline Power Model C & $\mathrm{BD}=\mathrm{a}(\mathrm{TW})^{\mathrm{b}}+\mathrm{c}(\mathrm{dk})^{\mathrm{d}}$ & -253.8 & 0.877 & -0.680 & 0.443 & 1.470 & 0.904 \\
\hline 2-Variable Linear & $\mathrm{BD}=\mathrm{a}+\mathrm{b}(\mathrm{TW})+\mathrm{c}(\mathrm{dk})$ & -246.7 & 0.880 & 6.10 & -0.365 & 0.889 & \\
\hline Power Model 1 & $B D=d k+\left(T W^{b}\right)(a(d k)+c)$ & -257.9 & 0.880 & -0.120 & 0.260 & 5.890 & \\
\hline
\end{tabular}

without dockage should be exactly equal to $\mathrm{BD}$ with dockage, but these two models cannot handle $0 \%$ dockage properly. Thus, Power Model 1 (table 1) was selected as the best model for predicting BD with dockage from TW (without dockage) and level of dockage. The singlevariable models (BD as a function of TW only) in table 1 and figure 1 did not have any problem with $0 \%$ dockage, but neither model had as low a standard error value as the two-variable models.

The greater scatter in the Goodland data was evaluated using a cross validation statistical analysis, following the procedure in Casada and Armstrong (2009). This analysis used a correlation equation which included dockage as an independent variable and showed (table 2) the expected high standard error from the Goodland data. The Goodland data was also poorly predicted (SEP $=1.12 \mathrm{lb} / \mathrm{bu}$ ) by the calibration from the other two locations compared to the predictions (SEP $<0.7 \mathrm{lb} / \mathrm{bu}$ ) of the other two individual locations when they were left out of the calibrations. These results indicate that the correlation from the entire dataset is required to predict $\mathrm{BD}$ with dockage from TW (without dockage) for poor quality, high-dockage samples (dockage levels above $1.0 \%$ ) like those in the Goodland data. For a normal harvest and normal dockage levels (dockage levels below $1.0 \%$ ) a limited correlation from only the two locations with normal dockage levels could probably be used. Such a correlation from only two locations with

Table 2. Cross-validation results: standard errors for TW from three locations. ${ }^{[a]}$

\begin{tabular}{lcccc}
\hline & Location Left & \multicolumn{3}{c}{ Standard Errors $(\mathrm{lb} / \mathrm{bu})^{[\mathrm{b}]}$} \\
\cline { 3 - 5 } Locations Included & Out & SEC & SEP & $\mathrm{SE}_{\text {location }}$ \\
\hline Enid \& Goodland & Manhattan & 0.93 & 0.68 & $0.61\left(\mathrm{SE}_{\text {Manhattan }}\right)$ \\
Enid \& Manhattan & Goodland & 0.54 & 1.12 & $0.80\left(\mathrm{SE}_{\text {Goodlland }}\right)$ \\
Goodland \& Manhattan & Enid & 0.97 & 0.61 & $0.61\left(\mathrm{SE}_{\text {Enid }}\right)$ \\
\hline Average: & & $\mathbf{0 . 8 1}$ & $\mathbf{0 . 8 1}$ & $\mathbf{0 . 6 7}$
\end{tabular}

[a] Model: $\mathrm{BD}=\mathrm{TW}+\left(\mathrm{dk}^{\mathrm{b}}\right) \cdot(\mathrm{a} \cdot \mathrm{TW}+\mathrm{c})$, please refer to table 2 for model details.

$\mathrm{BD}=$ bulk density $\mathrm{w} /$ dockage, $\mathrm{lb} / \mathrm{bu} ; \mathrm{TW}=$ test weight, $\mathrm{lb} / \mathrm{bu}$; $\mathrm{dk}=$ dockage, $\%$.

[b] $\mathrm{SEC}=$ standard error of calibration from combined data from two locations.

$\mathrm{SEP}=$ standard error of prediction for the location that was left out. $\mathrm{SE}_{\text {location }}=$ standard error for the single location (denoted by the subscript) left out. normal harvest conditions would lack robustness and was not pursued further.

\section{LABORATORY STUDY}

The greatest scatter in the field data occurred with the Goodland, Kansas samples, which often had unusually high dockage values (up to 3\%) that are rare for field data. The effect of high dockage levels (above 1\%) was not clear from the limited examples in the field data, so these effects were further evaluated with separate, initially clean wheat samples from four states that were mixed with dockage at levels from $0.05 \%$ to $5 \%$ under normal laboratory conditions. The highest dockage of 5\% was included to clarify dockage effects even though this was even higher than the highest dockage level found in the field data. BD with dockage was lower than TW without dockage because dockage is a lighter material than wheat kernels, which in turn lowers the BD. Also, the presence of the dockage material may have reduced the compaction of the whole wheat kernels. The difference between the BD and TW values was calculated for each sample and this decrease in BD caused by dockage was plotted as a function of dockage level (fig. 2). The plot showed a non-linear trend that was fit using a second order polynomial.

Based on the observed standard deviations, and using the $z$-value for a $5 \%$ margin of error, the minimum number of observations should be 20. Figure 2 shows the field samples, grouped by dockage level in $0.1 \%$ increments, when there were at least 20 observations. This minimum of 20 observations eliminated the high dockage level readings, mostly from the Goodland data, and all the field data in figure 2 had dockage levels below $0.75 \%$. According to the FGIS handbook (USDA-GIPSA, 2009), any dockage between $0 \%$ and $0.1 \%$, should be reported as $0 \%$. The average of cases with $0 \%$ dockage did not show BD with dockage equal to TW values, apparently because there was, on average, $0.05 \%$ dockage in those samples. Hence, for field data in figure 2 the dockage level that was reported as $0 \%$ is shown as $0.05 \%$, assuming $0.05 \%$ was the average dockage for samples between $0 \%$ and $0.1 \%$.

Figure 2 shows that the relationship between the decrease in $\mathrm{BD}$ and dockage level is nonlinear, with each of 
the second order polynomial having a goodness of fit $\left(\mathrm{R}^{2}\right)$ greater than 0.97 and SEM values ranging from 3.07E-03 to $6.79 \mathrm{E}-03$. The $\mathrm{R}^{2}$ values were used to compare these regression models because the coefficients were fit by linear regression (Steel and Torri, 1980). The apparent linear trend seen in the field data in figure 1 may have been because the effect of dockage level was not included (other than causing scatter) in the relationship in that figure. However, the broader range of dockage levels used in laboratory samples may have made the polynomial relationship more noticeable in figure 2 than it was with the narrow range of dockage in the field samples.

\section{CONCLUSIONS}

Predicting grain compaction requires knowledge of the BD with dockage; however, FGIS guidelines specify the TW for wheat is measured without dockage. These results allow the prediction of $\mathrm{BD}$ with dockage when dockage level and TW are known.

The following conclusions were drawn from this research:

1. Power Model 1 was selected as the best model for predicting BD with dockage from TW (without dockage) and level of dockage for HRW wheat field samples. The model was developed over the moisture range $10.0 \%$ to $12.9 \%(\mathrm{wb})$ and dockage levels of $0 \%$ to $3.2 \%$.

2. BD decrease caused by dockage is related to TW without dockage by a second order polynomial model that was developed over the range of $0.05 \%$ to $5 \%$ dockage, for both field and laboratory wheat samples consisting of HRW and SRW wheat classes.

3. The moisture range for all the wheat samples (including field and laboratory samples) in this study were from $8.8 \%$ to $13.3 \%(\mathrm{wb})$ and no significant correlation between $\mathrm{BD}$ and moisture levels of the samples in that range was found.

\section{ACKNOWLEDGEMENTS}

This research was supported by USDA (CRIS No. 543043440-007-00D) and the Kansas Agricultural Experiment Station (Contribution No. 15-405-J). Mention of trade names or commercial products in this article is solely for the purpose of providing specific information and does not imply recommendation or endorsement by the U.S. Department of Agriculture. USDA is an equal opportunity provider and employer. The assistance provided by Kevin Hamm (KSU) and Howell Gonzales (KSU) in conducting the field tests is highly appreciated.

We would like to thank Dalton Henry (Kansas Wheat

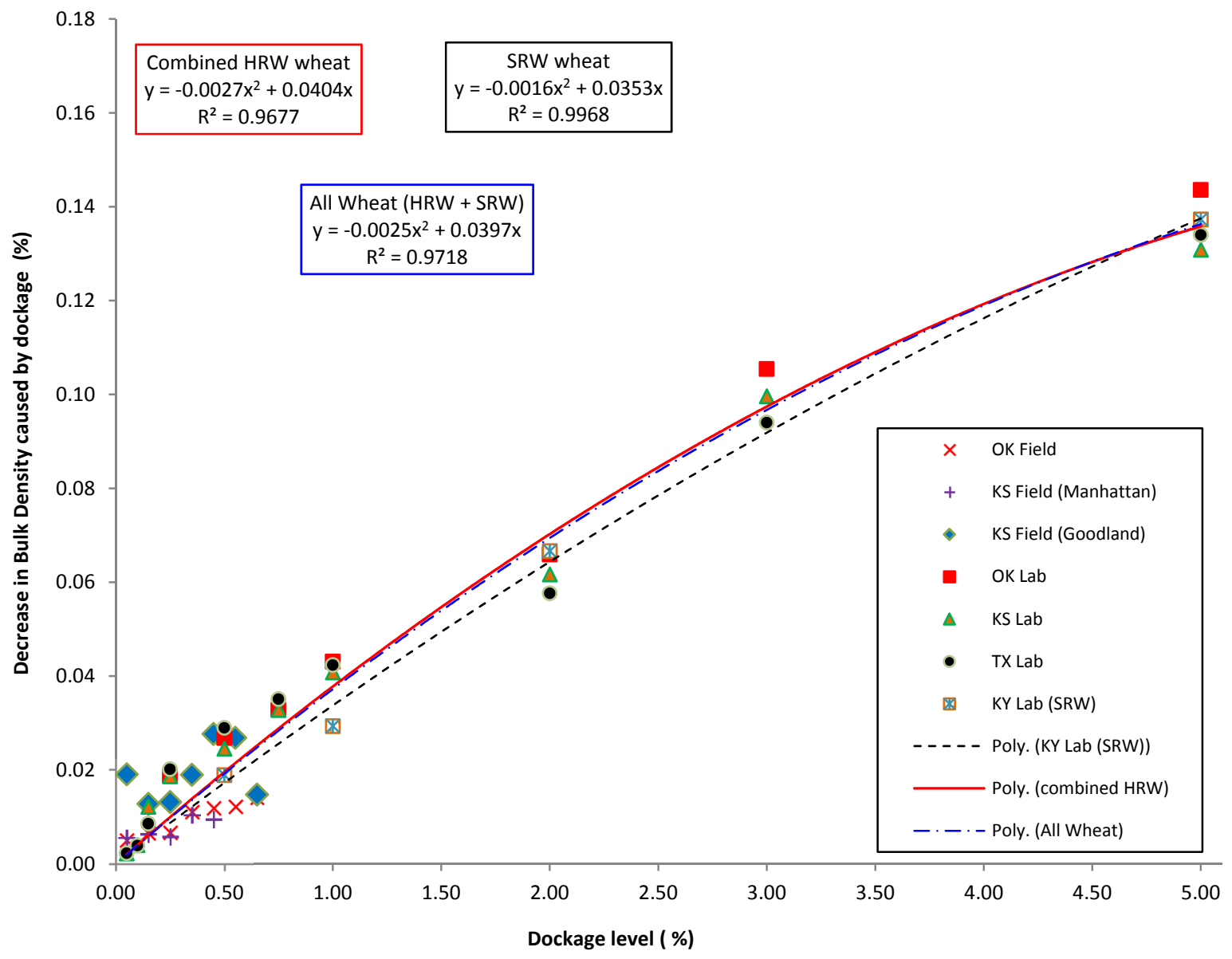

Figure 2. Decrease in bulk density due to dockage (\%) vs. dockage level (\%) for wheat samples from field and laboratory studies, with best fit polynomial curves for the HRW, SRW, and combined wheat samples. 
Commission), Richard Bauman (Frontier Ag, Inc.), Greg McLure (Riley County Extension Office), Mike Schulte (Oklahoma Wheat Commission), Ned Bergman and Steve Becker (Farm Service Agency), and Dr. Charles R. Hurburgh, Jr. (Iowa State University) and all of the extension specialists, university professors, and grain researchers who provided assistance in locating cooperators.

We also would like to thank our elevator-cooperators with HRW wheat bins: Joey Meibergen and Montie Walton of W.B. Johnston Terminal Elevator; Joshua Dechant of Frontier Ag, Inc.; and Doug Biswell of Manhattan Coop, Kansas.

\section{REFERENCES}

Akaike, H. (1974). A new look at the statistical model identification. IEEE Trans. Automatic Control, 19(6), 716-723. http://dx.doi.org/10.1109/TAC.1974.1100705

ASABE Standards. (2010). EP413.2: Procedure for establishing volumetric capacities of cylindrical bins. St. Joseph, MI: ASABE.

Bern, C., \& Brumm, T. J. (2009). Grain test weight deception. Ames: University Extension, Iowa State University. Retrieved from http://www.extension.iastate.edu/publications/pmr1005.pdf

Bhadra, R., Turner, A. P., Casada, M. E., Montross, M. D., Thompson, S. A., Boac, J. M., ... Maghirang, R. G. (2015). Pack factor measurements for corn in grain storage bins. Trans. ASABE, 58(3), 879-890. http://dx.doi.org/10.13031/trans.58.11033

Boac, J. M., Bhadra, R., Casada, M. E., Thompson, S. A., Turner, A. P., Montross, M. D., ... Maghirang, R. G. (2015). Stored grain pack factors for wheat: Comparison of three methods to field measurements. Trans. ASABE, 58(4), 1089-1101. http://dx.doi.org/10.13031/trans.58.10898

Casada, M. E., \& Armstrong, P. R. (2009). Wheat moisture measurement with a fringing field capacitive sensor. Trans. ASABE, 52(5), 1785-1791. http://dx.doi.org/10.13031/2013.29119

Chang, C. S., Converse, H. H., \& Martin, C. R. (1983). Bulk properties of grain as affected by self-propelled rotational type grain spreaders. Trans. ASABE, 26(5), 1543-1550.

$10.13031 / 2013.34167$
Chang, C. S., Shackelford, L. E., Lai, F. S., Martin, C. R., \& Miller, B. S. (1981). Bulk properties of corn as affected by multiplepoint grain spreaders. Trans. ASAE, 24(6), 1632-1636. http://dx.doi.org/10.13031/2013.34504

CurveExpert Professional Software, version 2.0.3. 2013. Developer: Daniel G. Hyams. Available at; https://www.curveexpert.net/

Fang, Y. (2011). Asymptotic equivalence between cross-validations and Akaike information criteria in mixed-effects models. J. Data Sci., 9(1), 15-21.

Janssen, H. A. (1895). Versuche uber getreidedruck in silozellen. Zeitschr. d. Vereines deutscher Ingenieure, 39(35), 1045-1049.

Loewer Jr., O. J., Ross, I. J., Kratzer, D. D., \& Walker, J. N. (1977). Properties of ground shelled corn as related to forces in bulk storage structures. Trans. ASAE, 20(1), 155-156. http://dx.doi.org/10.13031/2013.35512

Malm, J. K., \& Backer, L. F. (1985). Compaction factors for six crops. Trans. ASAE, 28(5), 1634-1636. http://dx.doi.org/10.13031/2013.32489

Matz S A 1991 Wheat. In: The Chemistry and Technology of Cereals as Food and Feed. Van Nostrand Reinhold, New York, USA, pp 1-61.

McNeill, S. G., Montross, M. D., Thompson, S. A., Ross, I. J., \& Bridges, T. C. (2008). Technical note: Packing factors of feed products in storage structures. Appl. Eng. Agric., 24(5), 625-630. http://dx.doi.org/10.13031/2013.25260

Milani, H. P., Bucklin, R. A., Teixeira, A. A., \& Kabeli, H. V. (2000). Soybean compressibility and bulk density. Trans. ASAE, 43(6), 1789-1793. http://dx.doi.org/10.13031/2013.3082

Steel, R. G. D., \& Torrie, J. H. (1980). Principles and procedures of statistics: A biometrical approach (2nd ed.). New York, NY: McGraw-Hill.

Thompson, S. A., \& Ross, I. J. (1983). Compressibility and frictional coefficients of wheat. Trans. ASAE, 26(4), 1171-1176. http://dx.doi.org/10.13031/2013.34099

Thompson, S. A., McNeill, S. G., Ross, I. J., \& Bridges, T. C. (1987). Packing factors of whole grains in storage structures. Appl. Eng. Agric., 3(2), 215-221. http://dx.doi.org/10.13031/2013.26677

USDA-GIPSA. (2009). Inspecting grain: Practical procedures for grain handlers. Washington, DC: USDA Grain Inspection, Packers and Stockyards Administration. Federal Grain Inspection Service. Retrieved from http://www.gipsa.usda.gov/Publications/pub_fgis.html\#hb 
Author(s)

\begin{tabular}{|l|l|l|l|c|}
\hline First Name & $\begin{array}{c}\text { Middle } \\
\text { Name }\end{array}$ & Surname & Role & $\begin{array}{c}\text { Type } \\
\text { (Corresp) }\end{array}$ \\
\hline Rumela & & Bhadra & $\begin{array}{l}\text { ASABE } \\
\text { Engineer and Rember } \\
\text { Associate }\end{array}$ & No \\
\hline
\end{tabular}

\section{Affiliation}

\begin{tabular}{|c|c|c|c|c|c|c|}
\hline \multicolumn{3}{|l|}{ Organization } & \multicolumn{2}{|l|}{ URL } & \multicolumn{2}{|l|}{ Email } \\
\hline \multicolumn{3}{|c|}{$\begin{array}{l}\text { Department of Biological and Agricultural } \\
\text { Engineering, Kansas State University, } \\
\text { Manhattan, Kansas }\end{array}$} & \multicolumn{2}{|l|}{ (optional) } & \multicolumn{2}{|c|}{ rbhadra@ksu.edu } \\
\hline \multicolumn{7}{|c|}{ Author(s) } \\
\hline First Name & $\begin{array}{l}\text { Middle } \\
\text { Name }\end{array}$ & \multicolumn{2}{|c|}{ Surname } & \multicolumn{2}{|l|}{ Role } & $\begin{array}{c}\text { Type } \\
\text { (Corresp) }\end{array}$ \\
\hline Mark & E. & \multicolumn{2}{|c|}{ Casada } & \multicolumn{2}{|c|}{$\begin{array}{l}\text { ASABE Member Engineer } \\
\text { and Research Agricultural } \\
\text { Engineer }\end{array}$} & Yes \\
\hline
\end{tabular}

Affiliation

\begin{tabular}{|c|c|c|c|c|c|c|}
\hline \multicolumn{3}{|c|}{ Organization } & \multicolumn{2}{|l|}{ URL } & \multicolumn{2}{|l|}{ Email } \\
\hline \multicolumn{3}{|c|}{$\begin{array}{l}\text { USDA-ARS Center for Grain and Animal } \\
\text { Health Research, Stored Product Insect and } \\
\text { Engineering Research Unit, } 1515 \text { College } \\
\text { Ave. Manhattan, Kansas, 66502; Phone: 785- } \\
\text { 776-2758; Fax: 785- }\end{array}$} & \multicolumn{2}{|l|}{ (optional) } & \multicolumn{2}{|c|}{ mark.casada@ars.usda.gov } \\
\hline \multicolumn{7}{|c|}{ Author(s) } \\
\hline First Name & $\begin{array}{l}\text { Middle } \\
\text { Name }\end{array}$ & \multicolumn{2}{|c|}{ Surname } & \multicolumn{2}{|l|}{ Role } & $\begin{array}{c}\text { Type } \\
\text { (Corresp) }\end{array}$ \\
\hline Josephine & $\mathrm{M}$ & \multicolumn{2}{|c|}{ Boac } & \begin{tabular}{l}
\multicolumn{2}{c}{ ASABE } \\
Engineer and \\
Associate
\end{tabular} & $\begin{array}{l}\text { Member } \\
\text { Research }\end{array}$ & No \\
\hline
\end{tabular}

Affiliation

\begin{tabular}{|l|l|l|}
\hline Organization & URL & Email \\
\hline $\begin{array}{c}\text { Kansas Department of Health and Envi- } \\
\text { ronment, Topeka, Kansas }\end{array}$ & (optional) & jboac@kdheks.gov \\
\hline
\end{tabular}

Author(s)

\begin{tabular}{|l|c|l|c|c|}
\hline First Name & $\begin{array}{c}\text { Middle } \\
\text { Name }\end{array}$ & Surname & Role & $\begin{array}{c}\text { Type } \\
\text { (Corresp) }\end{array}$ \\
\hline Aaron & P. & Turner & $\begin{array}{c}\text { ASABE Member Engineer } \\
\text { and Agricultural Engineer }\end{array}$ & No \\
\hline
\end{tabular}

Affiliation

\begin{tabular}{|l|l|l|}
\hline Organization & URL & Email \\
\hline $\begin{array}{l}\text { Department of Biosystems and Agricultural } \\
\text { Engineering, University of Kentucky, } \\
\text { Lexington, Kentucky }\end{array}$ & (optional) & aaron.turner@uky.edu \\
\hline
\end{tabular}

Author(s)

\begin{tabular}{|l|c|c|c|c|}
\hline First Name & $\begin{array}{c}\text { Middle } \\
\text { Name }\end{array}$ & Surname & Role & $\begin{array}{c}\text { Type } \\
\text { (Corresp) }\end{array}$ \\
\hline Sidney & A. & Thompson & $\begin{array}{c}\text { ASABE Member Engineer } \\
\text { and Professor }\end{array}$ & No \\
\hline
\end{tabular}

\section{Affiliation}

\begin{tabular}{|l|l|l|}
\hline Organization & URL & Email \\
\hline $\begin{array}{l}\text { Department of Biological and Agricultural } \\
\text { Engineering, University of Georgia, Athens, } \\
\text { Georgia }\end{array}$ & (optional) & sidt@engr.uga.edu \\
\hline
\end{tabular}

\section{Author(s)}




\begin{tabular}{|c|c|c|c|c|}
\hline First Name & $\begin{array}{c}\text { Middle } \\
\text { Name }\end{array}$ & Surname & Role & $\begin{array}{c}\text { Type } \\
(\text { Corresp) }\end{array}$ \\
\hline Michael & D. & Montross & $\begin{array}{c}\text { ASABE Member Engineer } \\
\text { and Associate Professor }\end{array}$ & No \\
\hline
\end{tabular}

\section{Affiliation}

\begin{tabular}{|c|c|c|c|c|c|c|}
\hline \multicolumn{3}{|l|}{ Organization } & \multicolumn{2}{|l|}{ URL } & \multicolumn{2}{|c|}{ Email } \\
\hline \multicolumn{3}{|c|}{$\begin{array}{l}\text { Department of Biosystems and Agricultural } \\
\text { Engineering, University of Kentucky, } \\
\text { Lexington, Kentucky }\end{array}$} & \multicolumn{2}{|l|}{ (optional) } & \multicolumn{2}{|c|}{ michael.montross@uky.edu } \\
\hline \multicolumn{7}{|c|}{ Author(s) } \\
\hline First Name & $\begin{array}{l}\text { Middle } \\
\text { Name }\end{array}$ & \multicolumn{2}{|c|}{ Surname } & \multicolumn{2}{|l|}{ Role } & $\begin{array}{c}\text { Type } \\
\text { (Corresp) }\end{array}$ \\
\hline Ronaldo & G. & \multicolumn{2}{|c|}{ Maghirang } & \multicolumn{2}{|c|}{$\begin{array}{l}\text { ASABE Member Engineer } \\
\text { and Professor }\end{array}$} & No \\
\hline
\end{tabular}

\section{Affiliation}

\begin{tabular}{|l|l|l|}
\hline Organization & URL & Email \\
\hline $\begin{array}{l}\text { Department of Biological and Agricultural } \\
\text { Engineering, Kansas State University, } \\
\text { Manhattan, Kansas }\end{array}$ & (optional) & rmaghir@ksu.edu \\
\hline
\end{tabular}

Manhattan, Kansas

Author(s)

\begin{tabular}{|l|c|c|c|c|}
\hline First Name & $\begin{array}{c}\text { Middle } \\
\text { Name }\end{array}$ & Surname & Role & $\begin{array}{c}\text { Type } \\
(\text { Corresp })\end{array}$ \\
\hline Samuel & G. & McNeill & $\begin{array}{l}\text { ASABE Member Engineer } \\
\text { and Associate Extension } \\
\text { Professor }\end{array}$ & No \\
\hline
\end{tabular}

\section{Affiliation}

\begin{tabular}{|l|l|l|}
\hline Organization & URL & Email \\
\hline Department of Biosystems and Agricultural & (optional) & sam.mcneill@uky.edu \\
Engineering, University of Kentucky, & & \\
Princeton, Kentucky & & \\
\hline
\end{tabular}

\section{Information about the Journal where this article will be published}

Full Title of the Journal Applied Engineering in Agriculture

DOI example only 10.13031/aea.29.10149

Pub Info

\begin{tabular}{|l|l|l|l|}
\hline Copyright or not & Year & Volume, Issue & Manuscript ID \\
\hline not & 2016 & $32(1)$ & PRS11692 \\
\hline
\end{tabular}

